\title{
Guidelines for IAEA Small Specimen Test Techniques Master Curve Fracture Toughness Testing
}

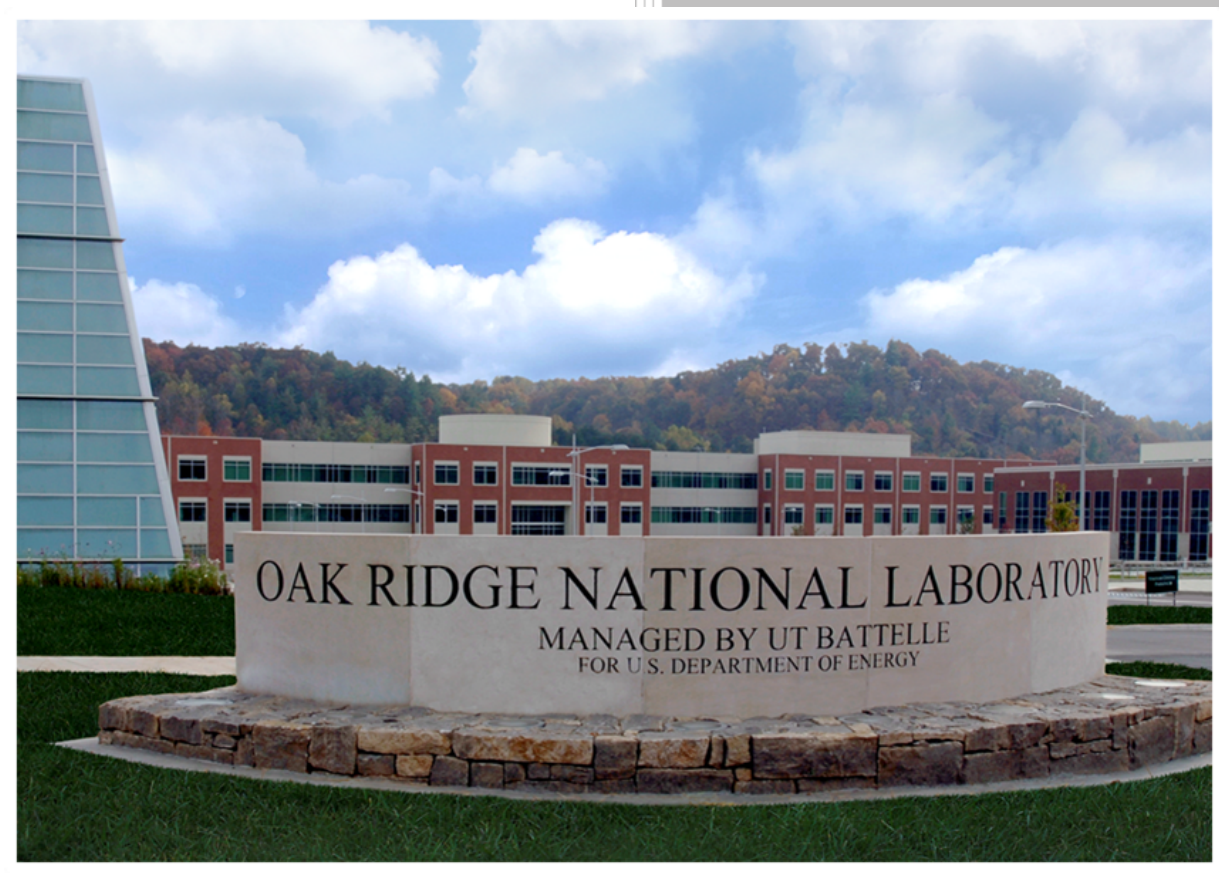

\section{Approved for public release}

OAK RIDGE NATIONAL LABORATORY
Xiang (Frank) Chen ${ }^{1}$

Rebeca Hernandez Pascual ${ }^{2}$ Marta Serrano ${ }^{2}$

David Andres ${ }^{3}$

Henk Nolles ${ }^{3}$

Mikhail A. Sokolov ${ }^{1}$

${ }^{1}$ Oak Ridge National Laboratory ${ }^{2}$ CIEMAT

${ }^{3}$ UK Atomic Energy Authority

July 2020 
This report was prepared as an account of work sponsored by an agency of the United States Government. Neither the United States Government nor any agency thereof, nor any of their employees, makes any warranty, express or implied, or assumes any legal liability or responsibility for the accuracy, completeness, or usefulness of any information, apparatus, product, or process disclosed, or represents that its use would not infringe privately owned rights. Reference herein to any specific commercial product, process, or service by trade name, trademark, manufacturer, or otherwise, does not necessarily constitute or imply its endorsement, recommendation, or favoring by the United States Government or any agency thereof. The views and opinions of authors expressed herein do not necessarily state or reflect those of the United States Government or any agency thereof. 
Materials Science and Technology Division

\section{Guidelines for IAEA Small Specimen Test Techniques Master Curve Fracture Toughness Testing}

Xiang (Frank) Chen ${ }^{1}$, Rebeca Hernandez Pascual$^{2}$, Marta Serrano ${ }^{2}$, David Andres ${ }^{3}$, Henk Nolles ${ }^{3}$,Mikhail A. Sokolov ${ }^{1}$

${ }^{1}$ Oak Ridge National Laboratory

${ }^{2}$ Centre for Energy, Environment and Technology (CIEMAT)

${ }^{3}$ UK Atomic Energy Authority

Date Published: July 2020

Prepared by

OAK RIDGE NATIONAL LABORATORY

Oak Ridge, TN 37831-6283

managed by

UT-BATTELLE, LLC

for the

US DEPARTMENT OF ENERGY

under contract DE-AC05-00OR22725 



\section{CONTENTS}

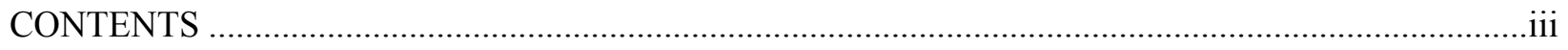

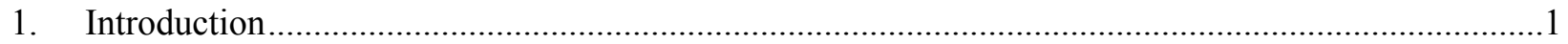

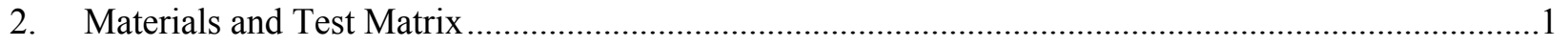

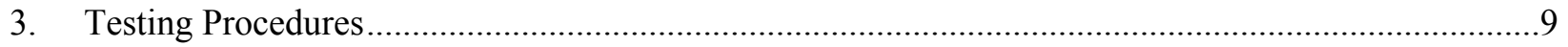

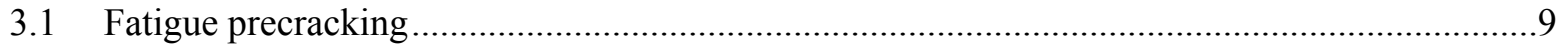

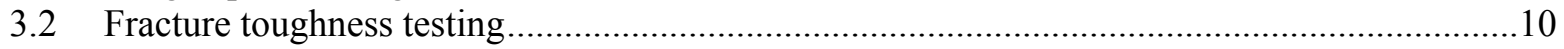

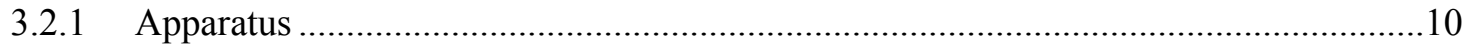

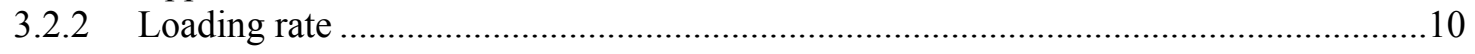

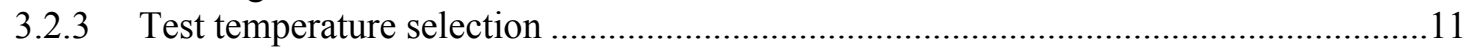

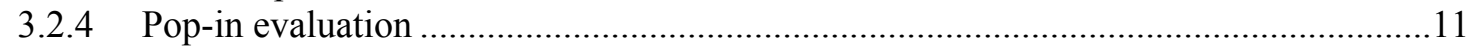

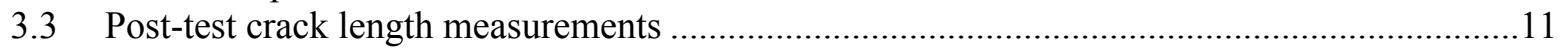

3.4 Fracture toughness calculation, validity check, and censoring ...........................................11

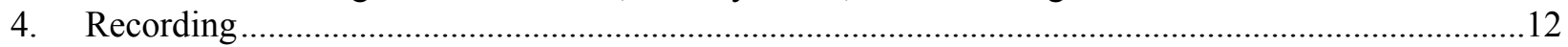

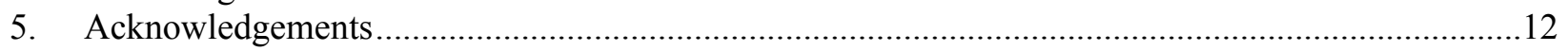

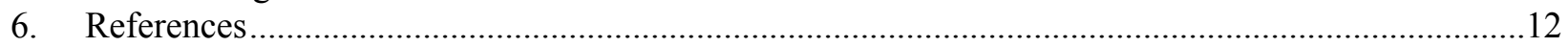




\section{Introduction}


Under the auspices of International Atomic Energy Agency (IAEA), a coordinated research project (CRP) entitled "Towards the Standardization of Small Specimen Test Techniques for Fusion Applications" has started since 2017. The overall objective of the project is to provide a set of guidelines for small specimen test techniques (SSTT) based on commonly agreed best practices on main test techniques including tensile, creep, low cycle fatigue, fracture toughness, and fatigue crack growth rate. This will act as the first step of a full standardization of the SSTT. Fusion structural materials, i.e., reduced activation ferritic/martensitic (RAFM) steels, are used for testing. In addition, the project will create a comprehensive mechanical property database of RAFM steels tested by SSTT.

For the fracture toughness task of the CRP, three testing methods including Master Curve, local approach for ductile crack growth and cleavage fracture, and ductile approach at room temperature will be evaluated. This report focuses on developing guidelines for the round-robin Master Curve testing based on the ASTM standard E1921-19b "Standard Test Method for Determination of Reference Temperature, $\mathrm{T}_{0}$, for Ferritic Steels in the Transition Range" [1] and commonly agreed best practice from researchers at Oak Ridge National Laboratory (ORNL), Centre for Energy, Environment and Technology (CIEMAT), and UK Atomic Energy Authority (UKAEA).

\section{Materials and Test Matrix}

The materials used in the round-robin testing are Eurofer 97 batch-3 and F82H-BA12. Table 1 summarizes the test matrix adopted in the round-robin testing. The specimen machining plan is highlighted in Fig. 1 with individual specimen drawings given in Figs. 2-8. Each participating laboratory will perform the machining independently. The standard specimen configuration and dimensions shall be in line with requirements in E1921-19 sections 7.1 to 7.4 where applicable.

Table 1 Master Curve round-robin testing matrix

\begin{tabular}{|c|c|c|c|c|c|}
\hline Participants & Materials & $\begin{array}{c}\text { Specimen } \\
\text { configuration }\end{array}$ & $\begin{array}{c}\text { \# of } \\
\text { specimens }\end{array}$ & Orientation & $\begin{array}{c}\text { Size of raw } \\
\text { material* }^{*}\end{array}$ \\
\hline \multirow{6}{*}{$\begin{array}{l}\text { X. Chen/M. } \\
\text { Sokolov } \\
\text { (ORNL) }\end{array}$} & \multirow{3}{*}{$\begin{array}{c}\text { Eurofer97 } \\
\text { batch-3 }\end{array}$} & $\begin{array}{c}\text { miniature bend } \\
\text { bar (Fig. } 2 \text { ) }\end{array}$ & 16 & \multirow{3}{*}{ LT } & \multirow{3}{*}{$\begin{array}{c}460 \mathrm{~mm}(\mathrm{~L}) \mathrm{x} \\
125 \mathrm{~mm}(\mathrm{~T}) \mathrm{x} \\
33 \mathrm{~mm}(\mathrm{~S})\end{array}$} \\
\hline & & miniCT (Fig.3) & $10-12$ & & \\
\hline & & 0.5TCT (Fig.4) & $8-10$ & & \\
\hline & \multirow{3}{*}{$\begin{array}{l}\mathrm{F} 82 \mathrm{H}- \\
\mathrm{BA} 12\end{array}$} & $\begin{array}{l}\text { miniature bend } \\
\text { bar (Fig. } 2 \text { ) }\end{array}$ & 16 & \multirow{3}{*}{ LT } & \multirow{3}{*}{$\begin{array}{c}100 \mathrm{~mm}(\mathrm{~L}) \mathrm{x} \\
300 \mathrm{~mm}(\mathrm{~T}) \mathrm{x} \\
26 \mathrm{~mm}(\mathrm{~S})\end{array}$} \\
\hline & & miniCT (Fig.3) & $10-12$ & & \\
\hline & & 0.5TCT (Fig.4) & $8-10$ & & \\
\hline \multirow{4}{*}{$\begin{array}{l}\text { R. Hernandez } \\
\text { Pascual/ M. } \\
\text { Serrano } \\
\text { (CIEMAT) }\end{array}$} & \multirow[b]{2}{*}{$\begin{array}{l}\text { Eurofer97 } \\
\text { batch-3 }\end{array}$} & PCCVN (Fig.5) & \multirow[b]{2}{*}{$8-10$} & \multirow[b]{2}{*}{ LT } & \multirow{2}{*}{$\begin{array}{c}600 \mathrm{~mm}(\mathrm{~L}) \mathrm{x} \\
125 \mathrm{~mm}(\mathrm{~T}) \mathrm{x} \\
33 \mathrm{~mm}(\mathrm{~S})\end{array}$} \\
\hline & & 0.5TCT (Fig.6) & & & \\
\hline & \multirow[b]{2}{*}{$\begin{array}{l}\mathrm{F} 82 \mathrm{H}- \\
\mathrm{BA} 12\end{array}$} & PCCVN (Fig.5) & \multirow[b]{2}{*}{$8-10$} & \multirow[b]{2}{*}{ LT } & \multirow{2}{*}{$\begin{array}{c}200 \mathrm{~mm}(\mathrm{~L}) \mathrm{x} \\
300 \mathrm{~mm}(\mathrm{~T}) \mathrm{x} \\
25 \mathrm{~mm}(\mathrm{~S})\end{array}$} \\
\hline & & 0.5TCT (Fig.6) & & & \\
\hline D. Andres (UK & Eurofer97 & $\operatorname{miniCT}($ Fig. 7 ) & $10-12$ & LT & $50 \mathrm{~mm}(\mathrm{~L}) \mathrm{x}$ \\
\hline
\end{tabular}




\begin{tabular}{|c|c|c|c|c|c|}
\hline \multirow[t]{3}{*}{ AEA) } & batch-3 & $\begin{array}{c}\text { miniCT-DONES } \\
\text { (Fig. 8) }\end{array}$ & $10-12$ & & $\begin{array}{c}120 \mathrm{~mm}(\mathrm{~T}) \times \\
33 \mathrm{~mm}(\mathrm{~S})\end{array}$ \\
\hline & \multirow[b]{2}{*}{$\begin{array}{c}\text { F82H- } \\
\text { BA12 }\end{array}$} & miniCT (Fig. 7) & $10-12$ & \multirow[b]{2}{*}{ LT } & \multirow{2}{*}{$\begin{array}{c}40 \mathrm{~mm}(\mathrm{~L}) \mathrm{x} \\
60 \mathrm{~mm}(\mathrm{~T}) \mathrm{x} \\
25 \mathrm{~mm}(\mathrm{~S}) \\
(\mathrm{TBD})\end{array}$} \\
\hline & & $\begin{array}{c}\text { miniCT-DONES } \\
\text { (Fig. 8) }\end{array}$ & $10-12$ & & \\
\hline
\end{tabular}

* L: longitudinal, T: transverse, and S: short transverse based on the plate orientation

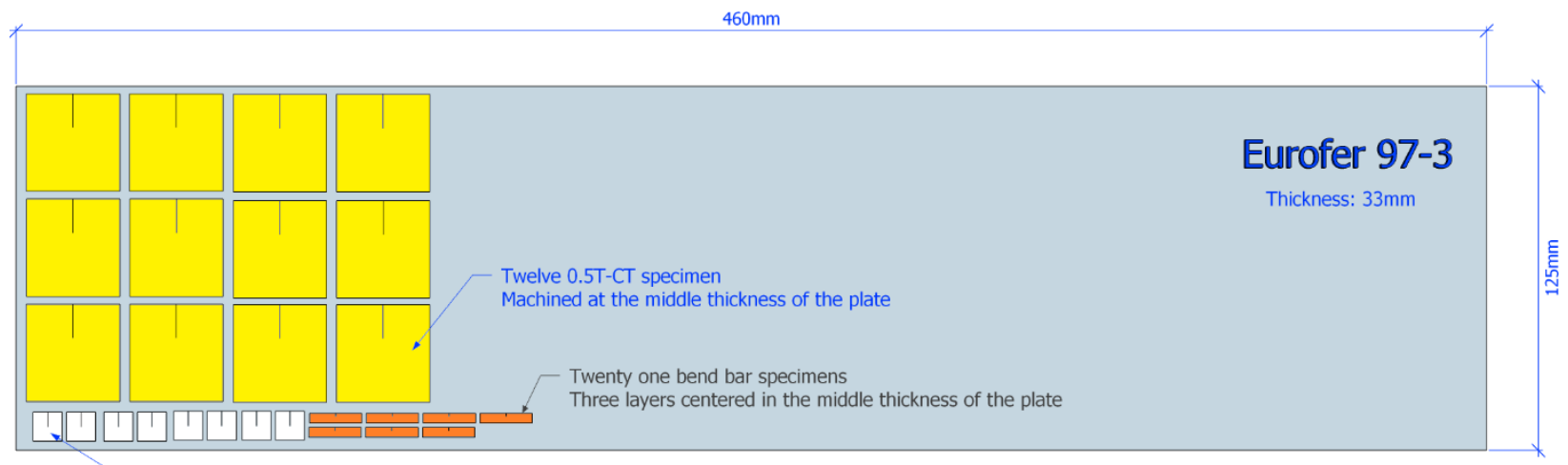

Sixteen minicT specimens

Two layers centered in the middle thickness of the plate

(a)

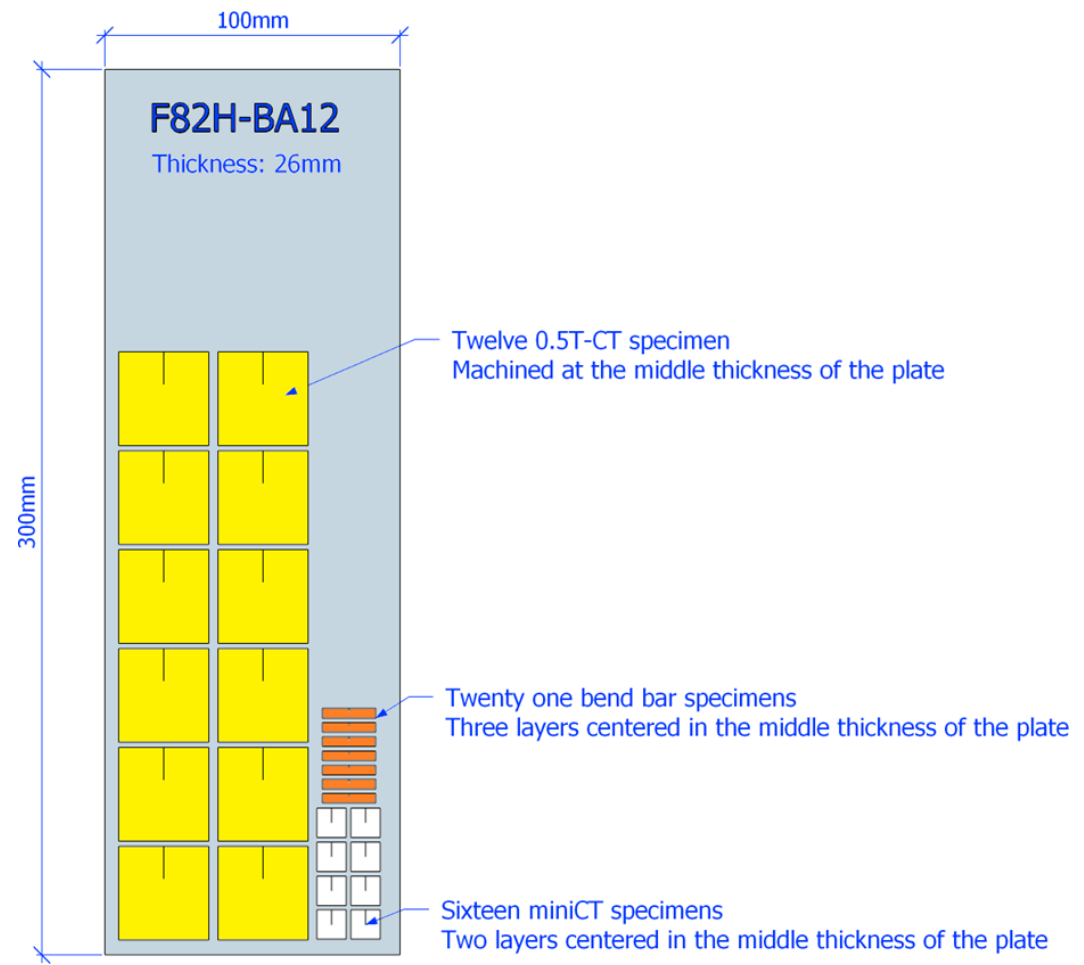

(b) 

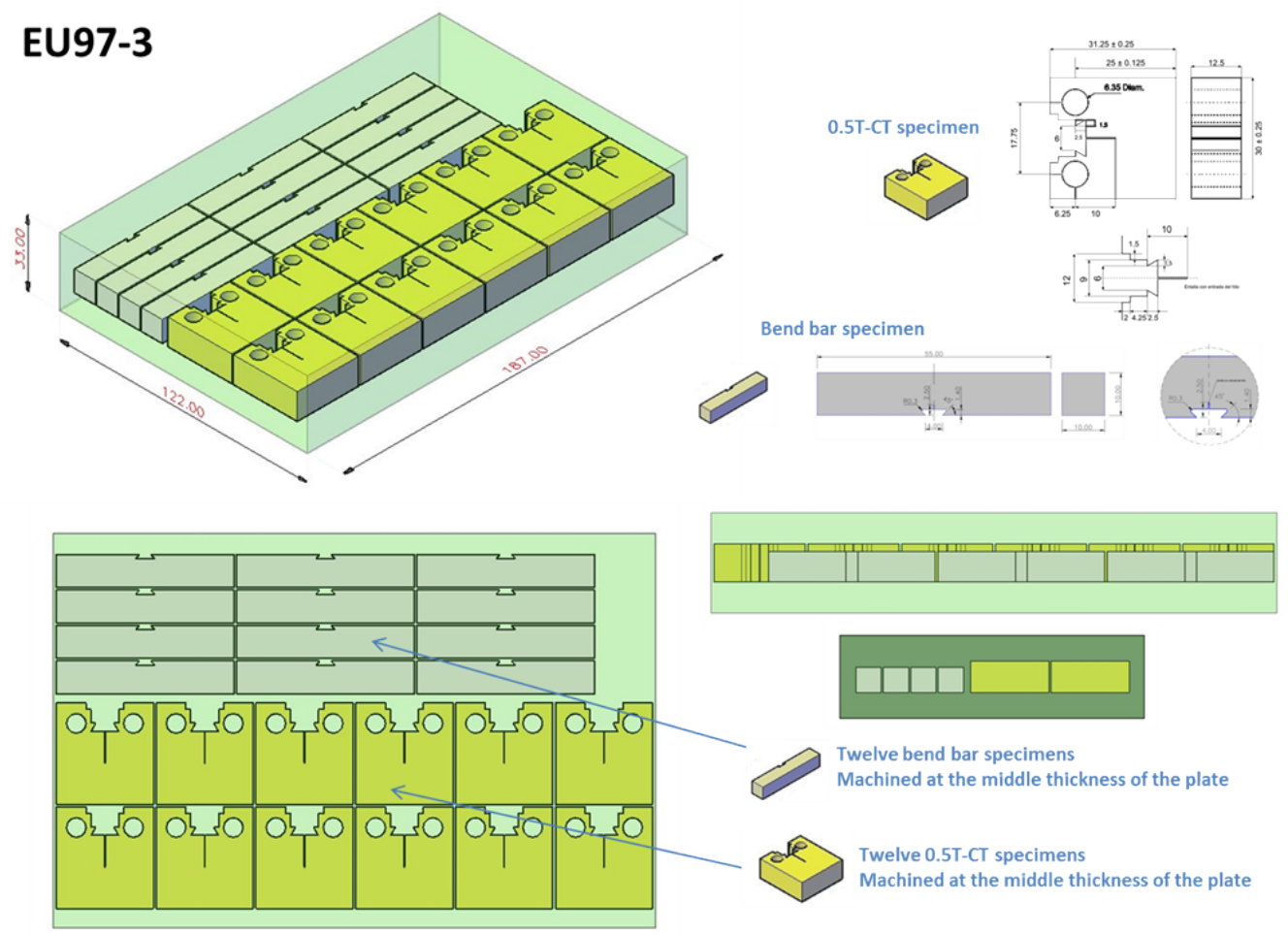

(c)

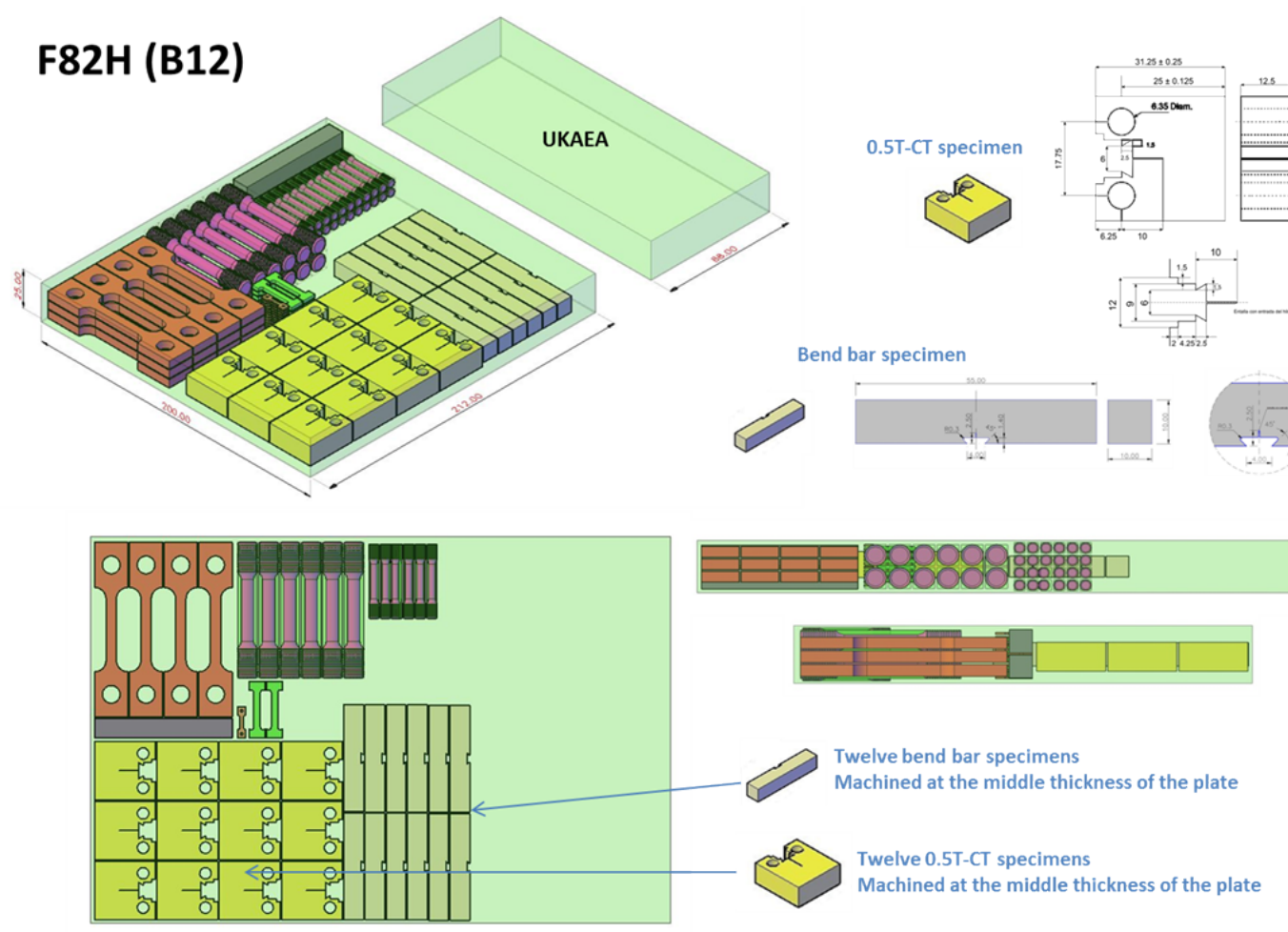

(d) 

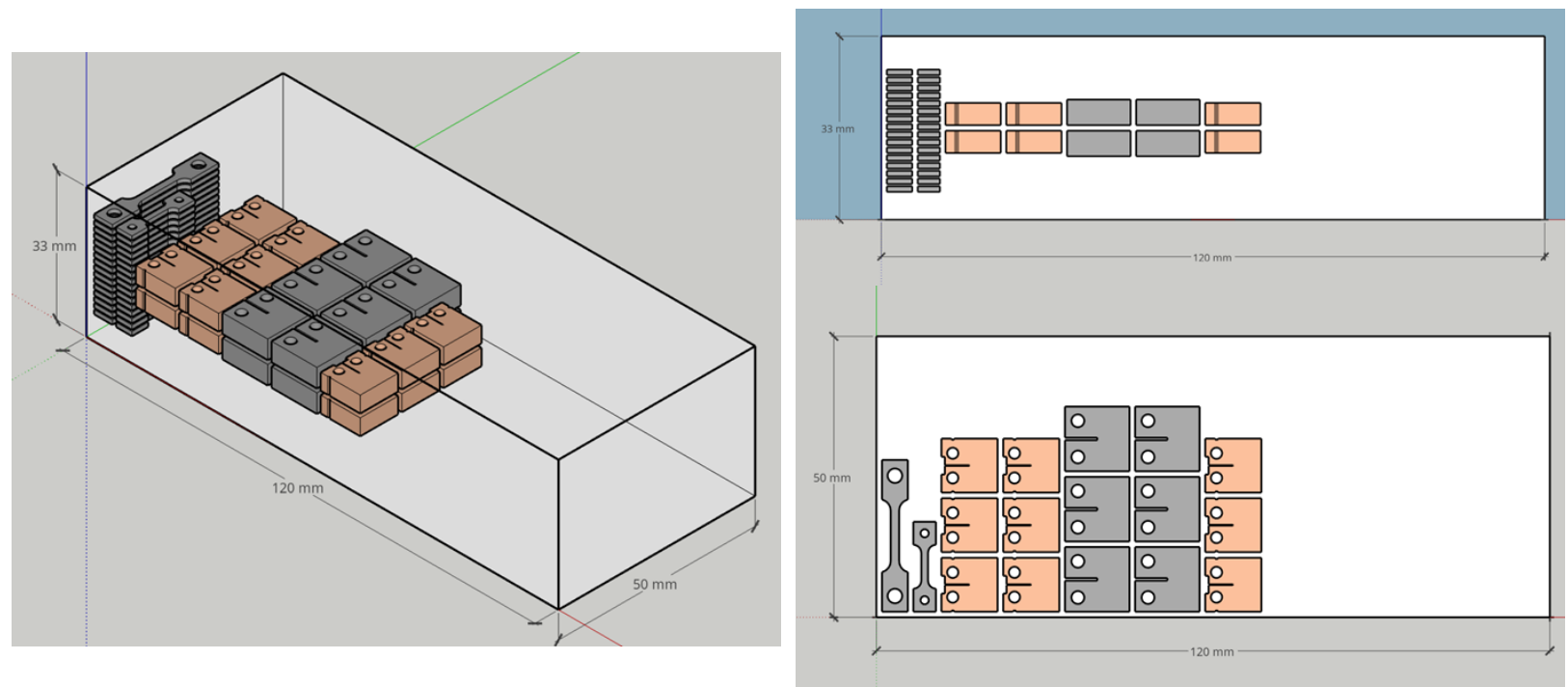

Eurofer97-3 machining plan (Specimens from left to right: DONES tensile, SSJ3 tensile, mCT-MRF, mCT-DONES, $\mathrm{mCT}-\mathrm{MRF}$ for $\mathrm{FCG})(\mathrm{TBD})$

(e)
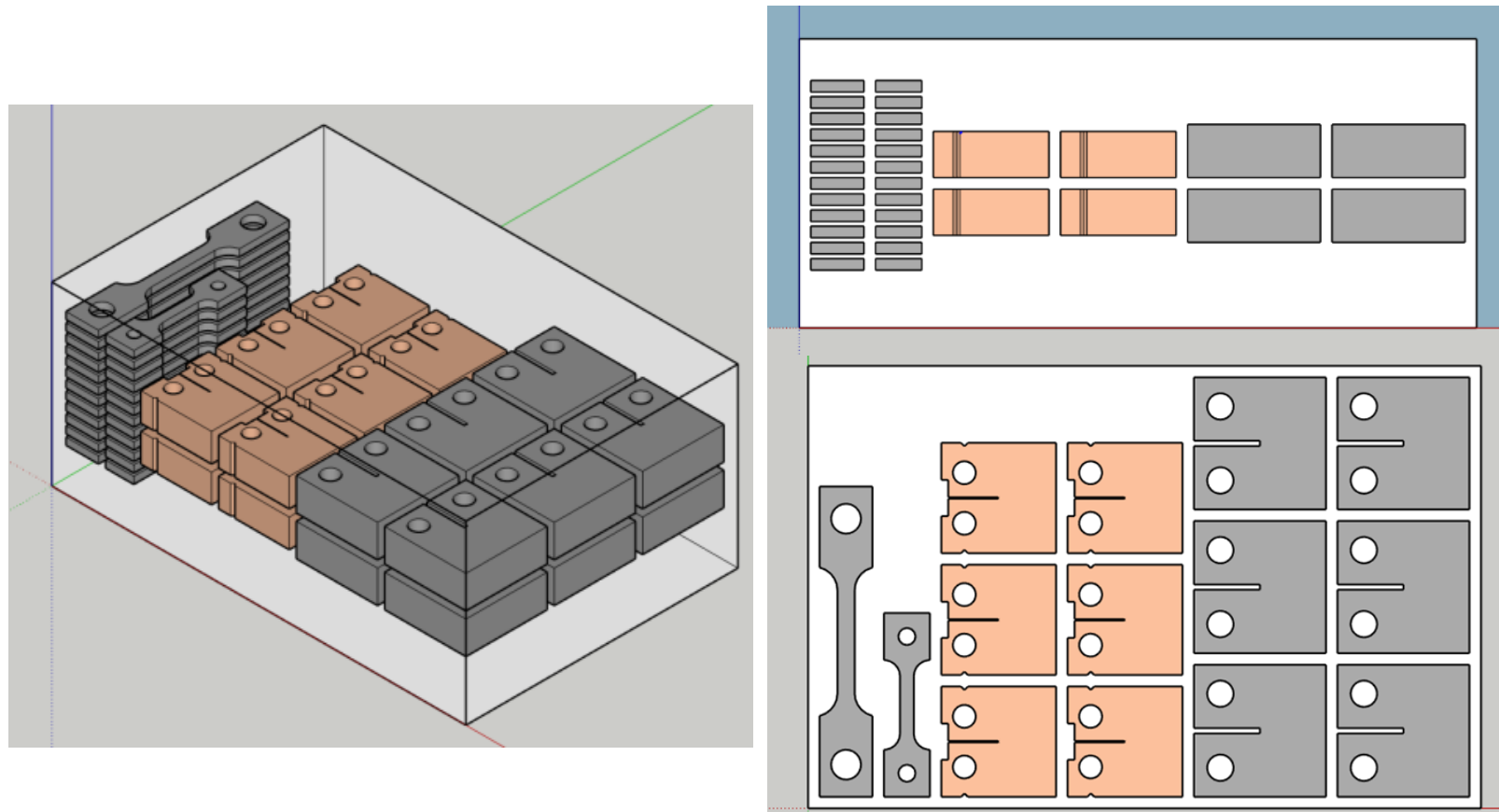

UKAEA F82H-BA12 machining plan (Specimens from left to right: DONES tensile, SSJ3 tensile, mCTMRF, mCT-DONES.) (TBD)

(f)

Fig. 1 Specimen machining plans for ORNL in (a) and (b), CIEMAT in (c) and (d), and UKAEA in (e) and (f). 


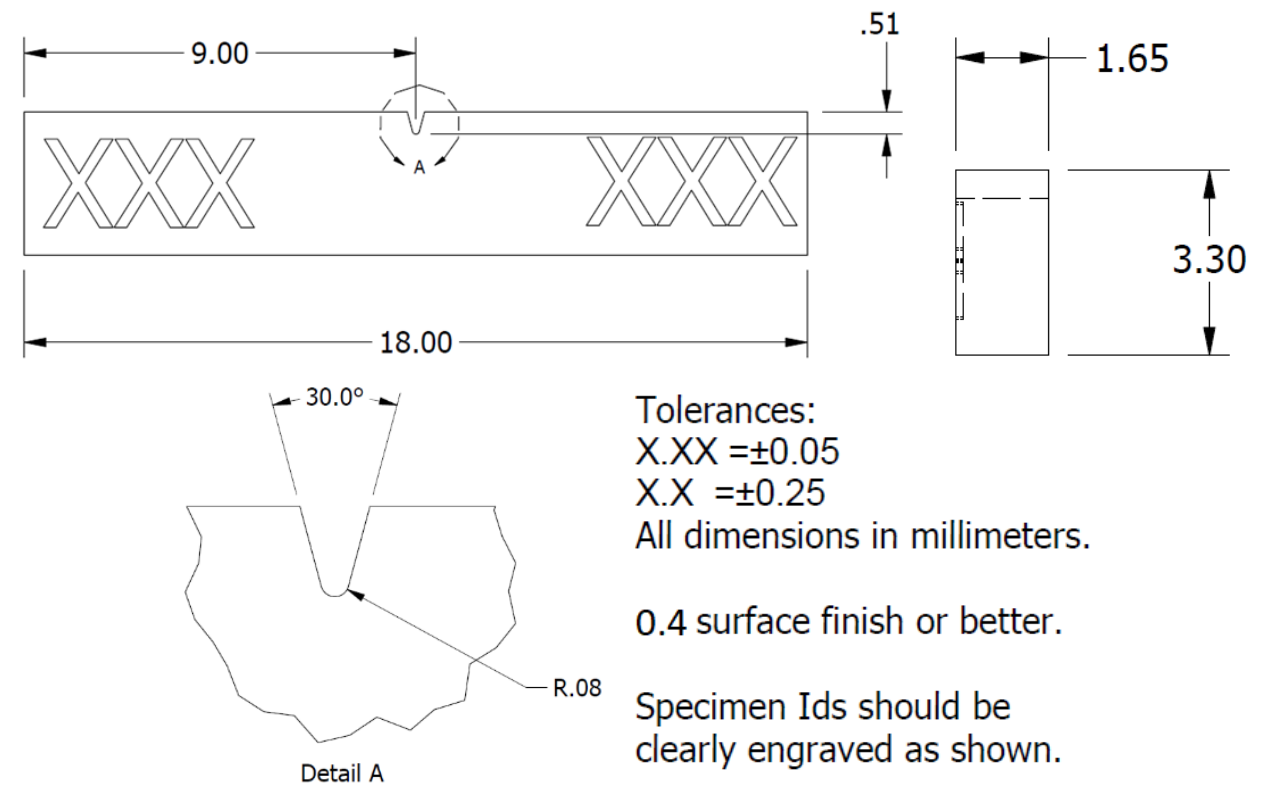

Fig. 2 ORNL miniature bend bar specimen drawing.

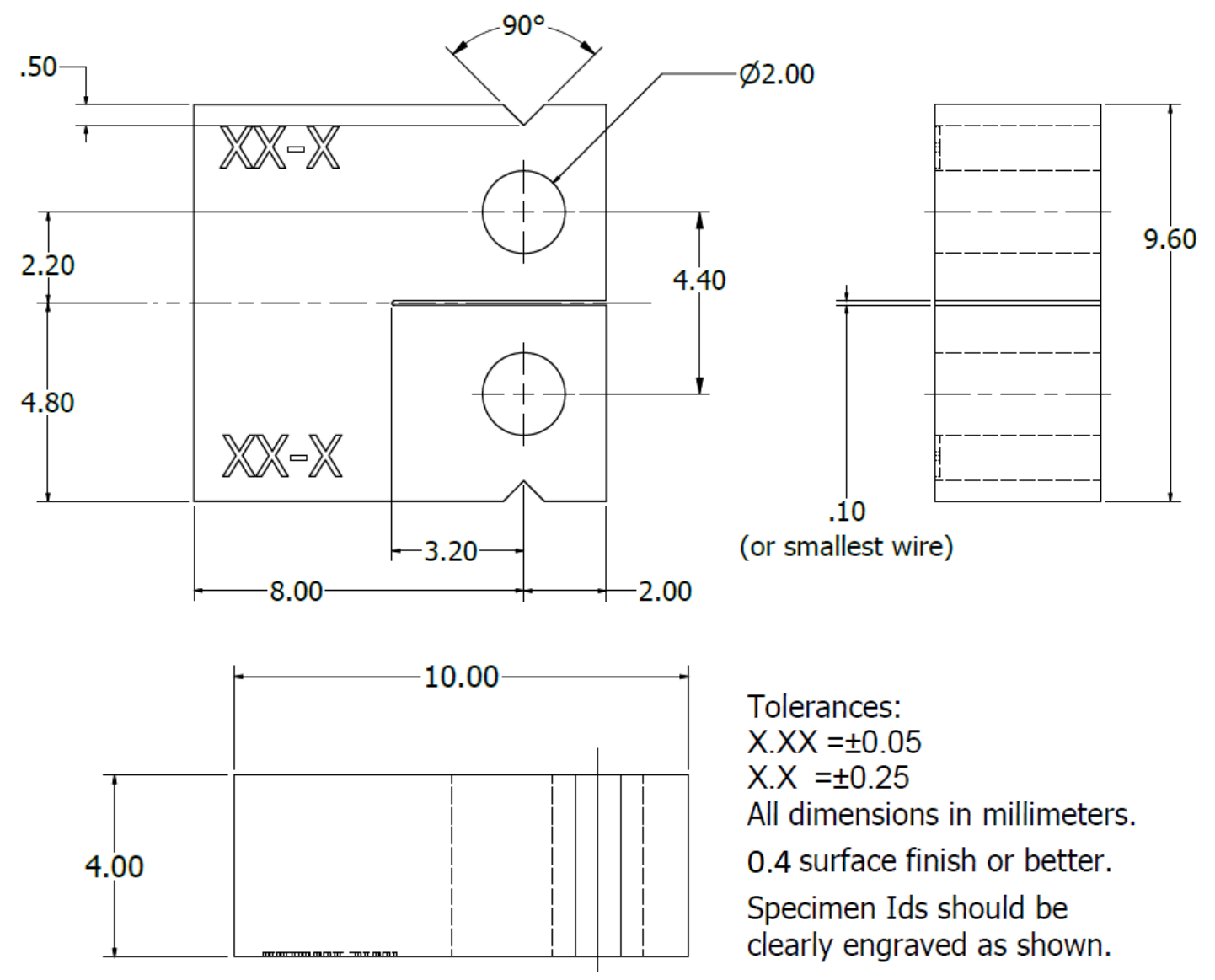

Fig. 3 ORNL miniCT specimen drawing. 


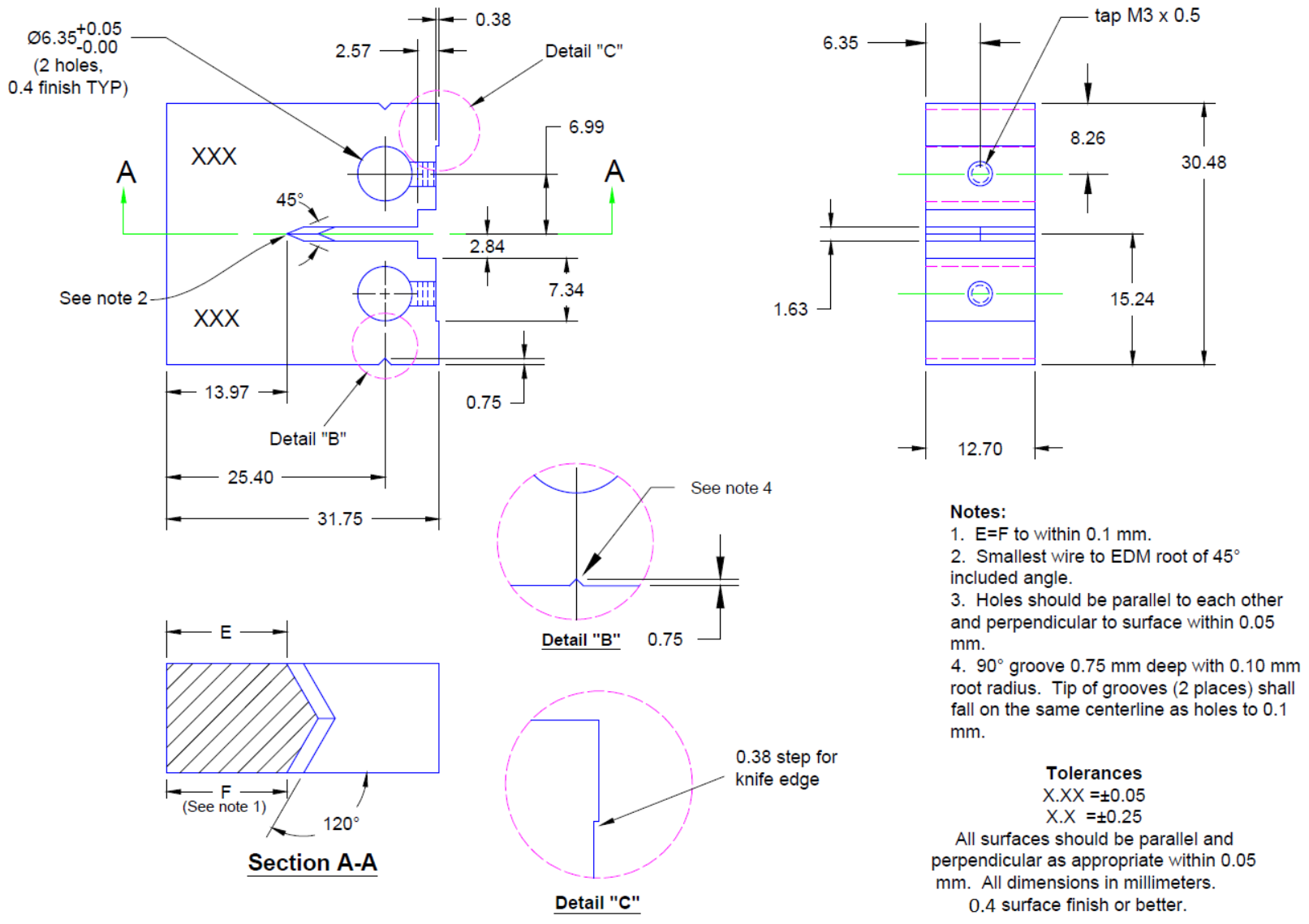

Fig. 4 ORNL 0.5TCT specimen drawing.
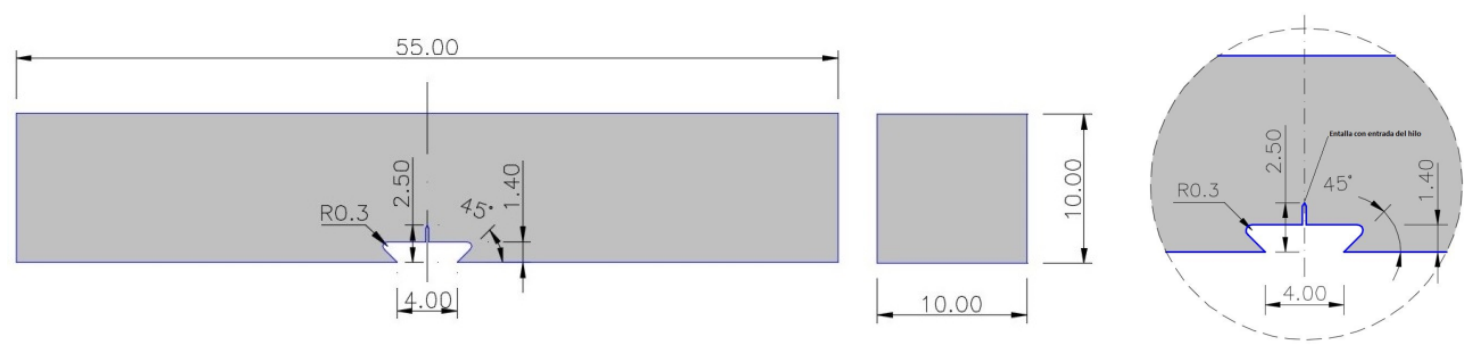

Fig. 5 CIEMAT PCCVN specimen drawing 


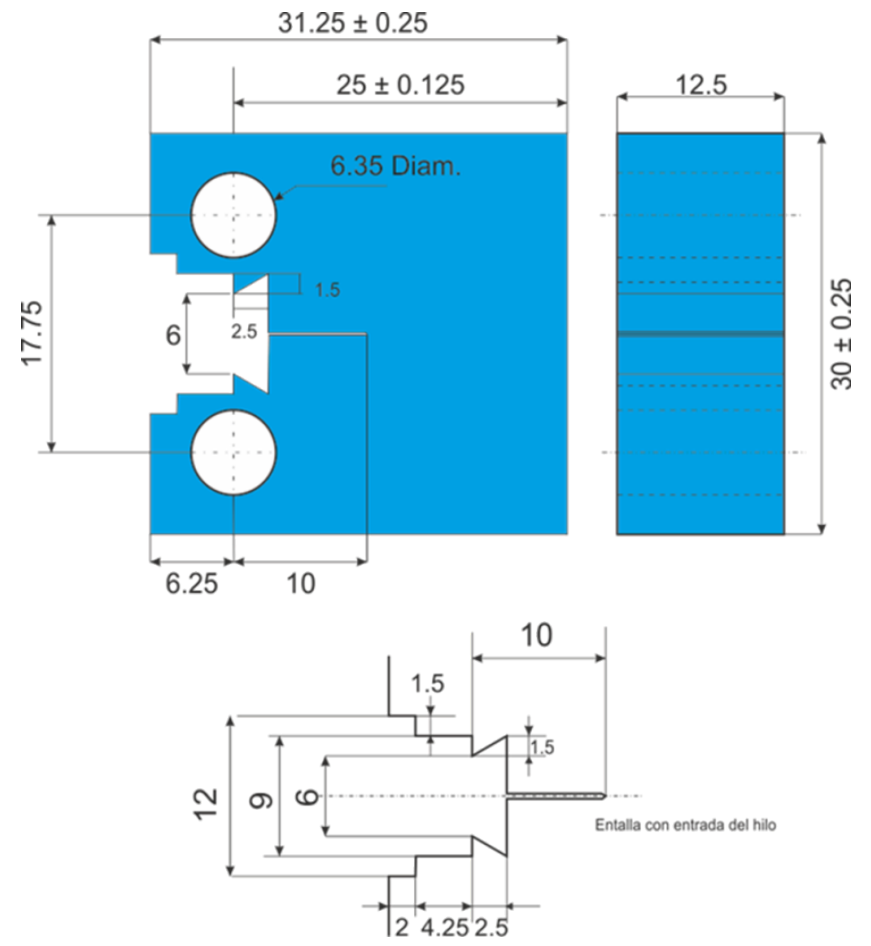

Fig. 6 CIEMAT 0.5TCT specimen drawing
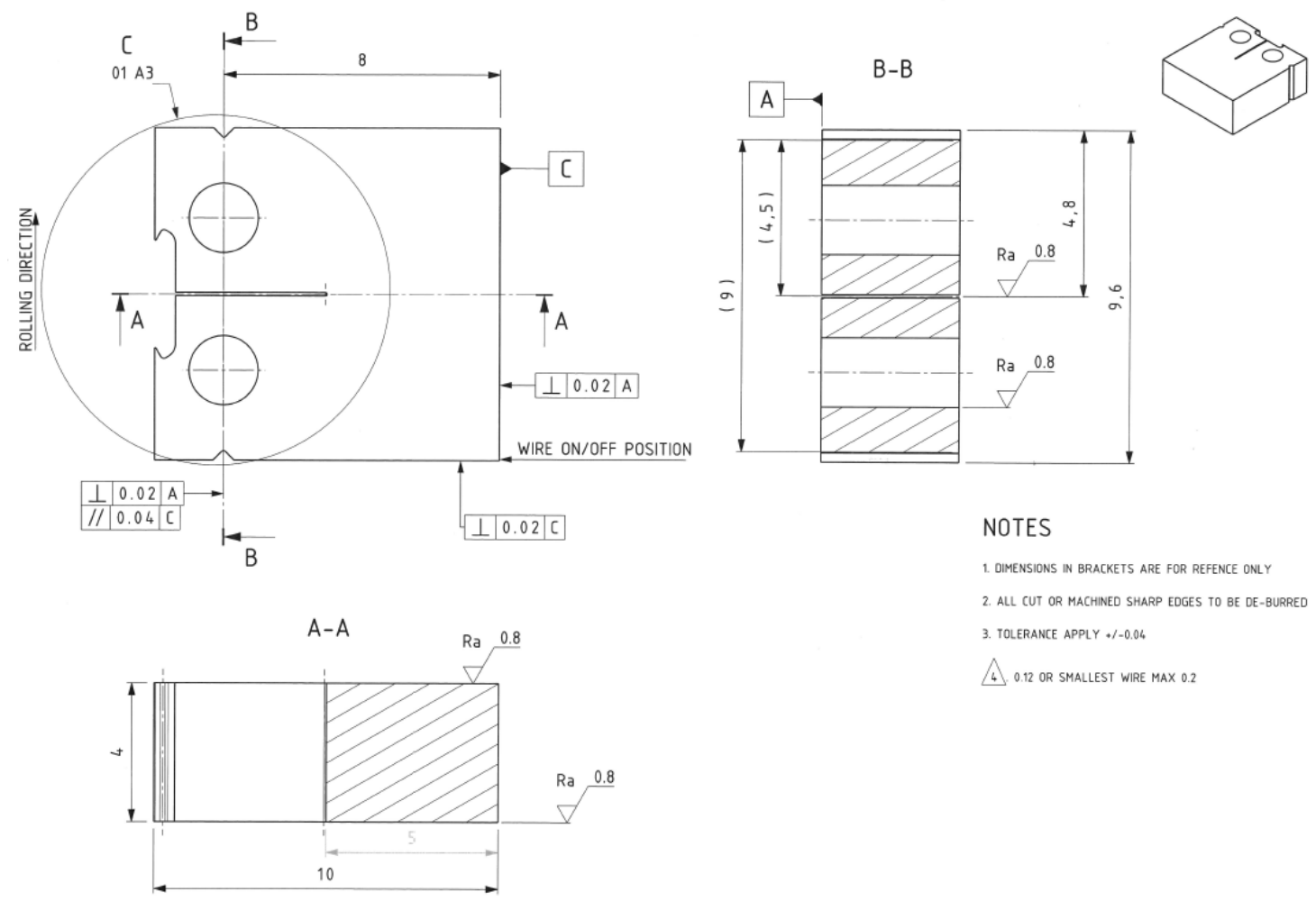

1. OIMENSIONS IN BRACKETS ARE FOR REFENCE ONLY

2. ALL CUT OR MACHINED SHARP EDGES TO BE DE-BURRED 3. TOLERANCE APPLY $* /-0.04$

4. 0.12 or smallest Wire MaX 0.2

(a) 


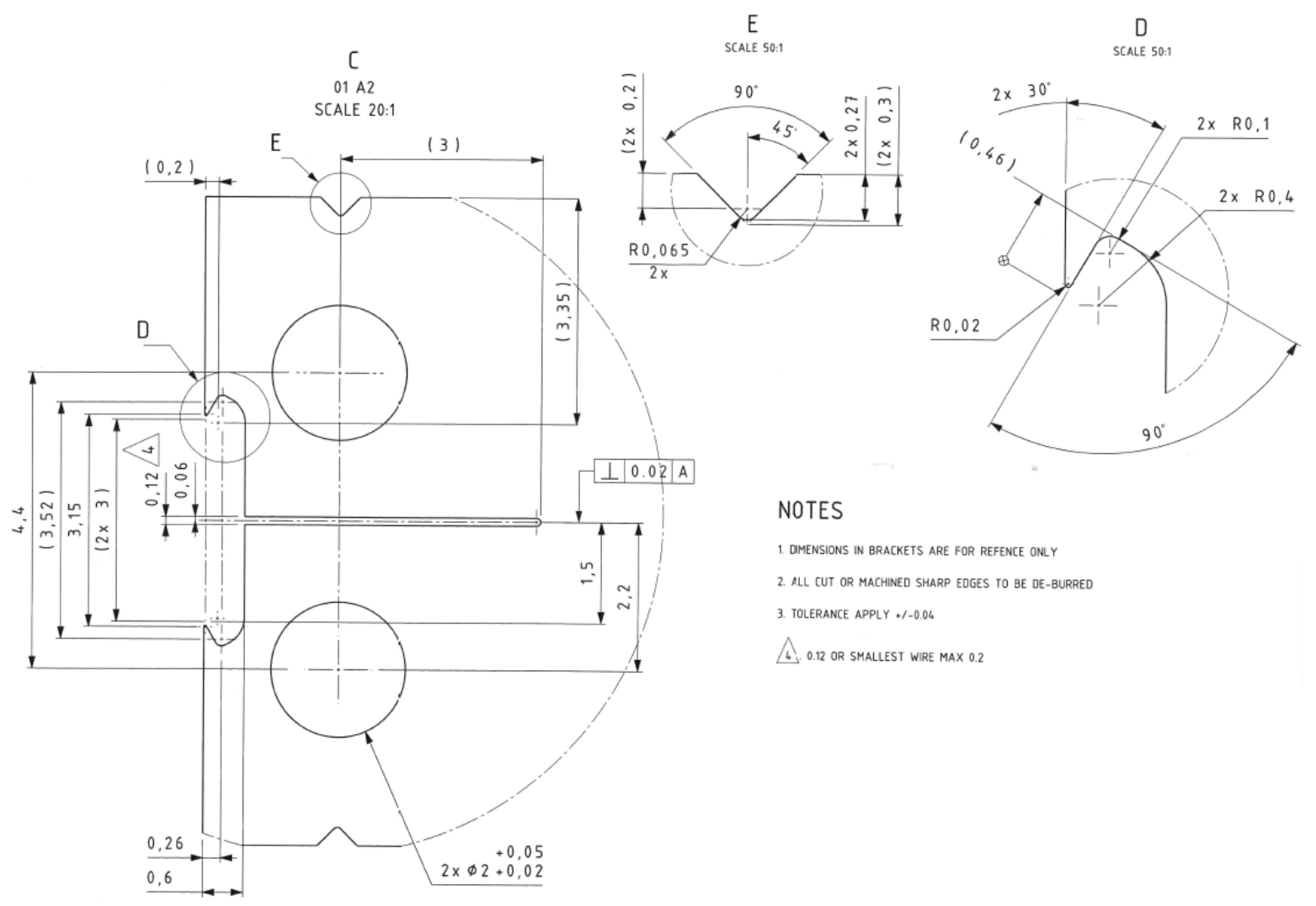

(b)

Fig. 7 UKAEA miniCT specimen drawing: (a) general layout, (b) details of the drawing
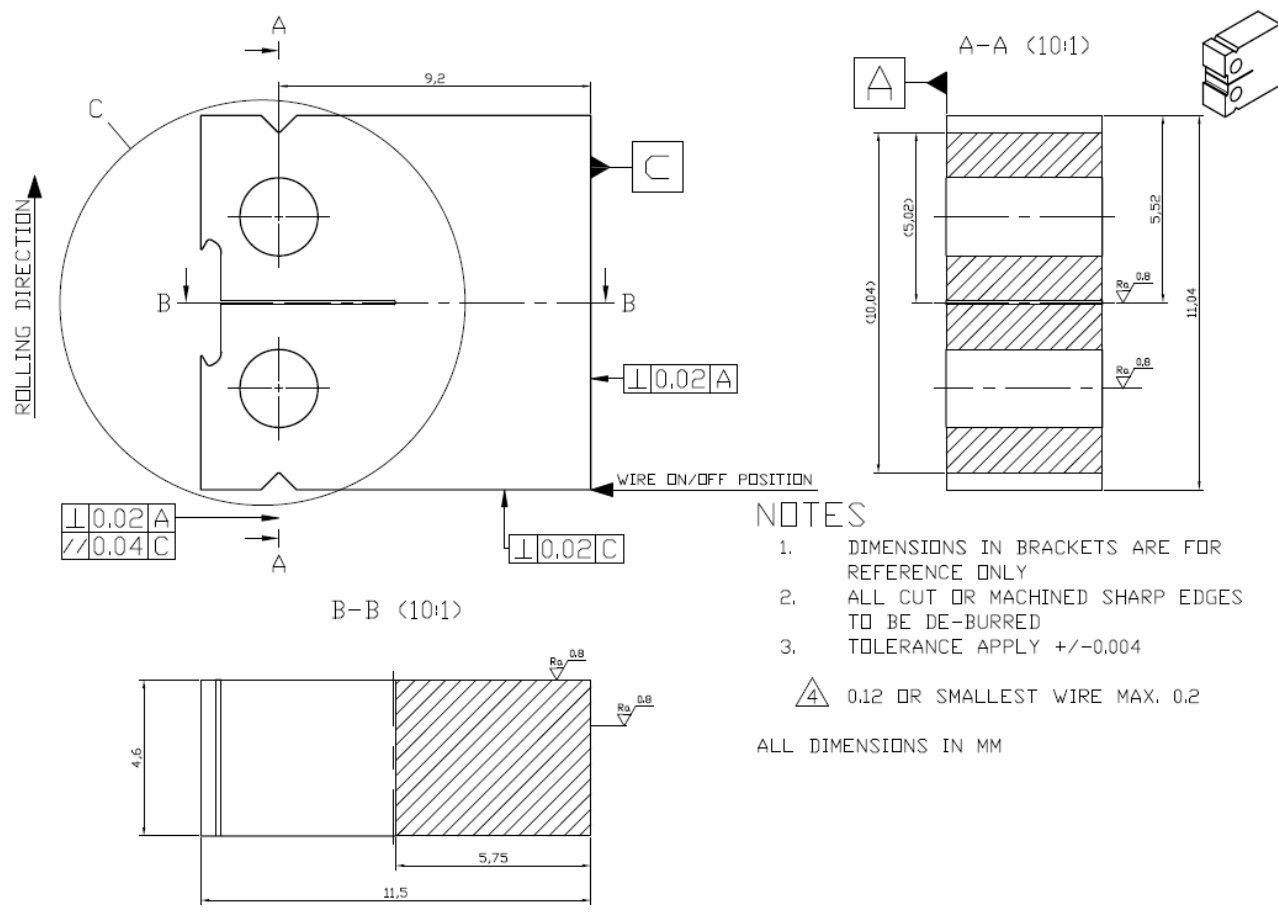

ALL DIMENSIUNS IN MM

(a) 


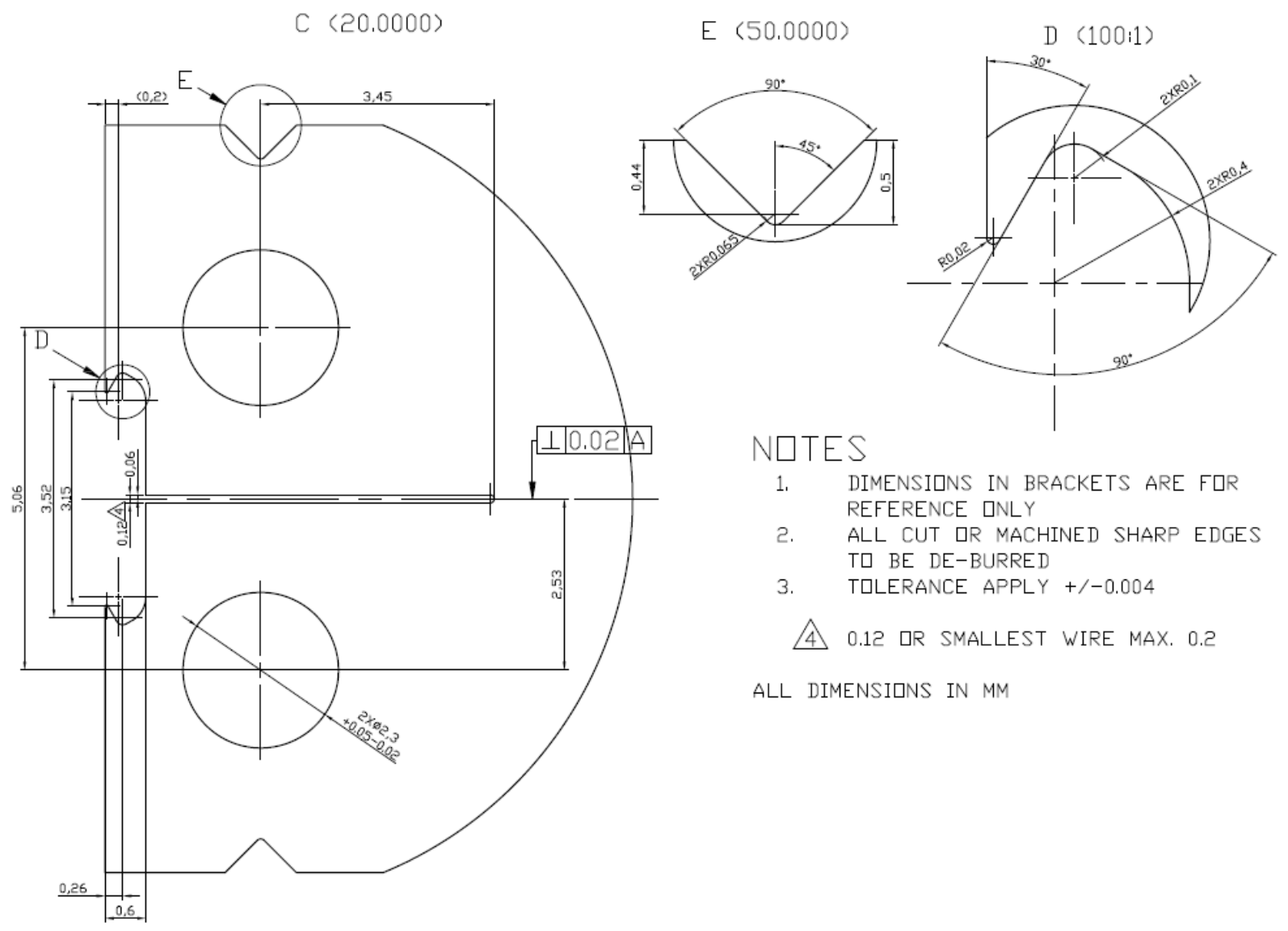

(b)

Fig. 8 UKAEA miniCT-DONES specimen drawing based on the proposed DONES mCT with $\mathrm{W}=9.2 \mathrm{~mm}$ : (a) general layout, (b) details of the drawing

\section{Testing Procedures}

\subsection{Fatigue precracking}

Main specimen dimensions, such as B (specimen thickness) and W (specimen width), should be measured from each specimen before fatigue precracking. The precracking can be conducted under either force control, displacement control, or K (stress intensity) control. The load cell and displacement gage for specimens shall be calibrated to related ASTM standards or other recognized national or international standards. Fatigue cycling is conducted using a sinusoidal waveform and a frequency close to the highest practical value of the test frame. Precracking is generally most effectively conducted using $\mathrm{R}=\mathrm{P}_{\min } / \mathrm{P}_{\max }=$ 0.1. There are four main requirements need to be fulfilled for fatigue precracking:

1) The maximum fatigue force is less than $P_{m}$ (control force) as defined in the equations below:

$$
\text { For } \mathrm{SE}(\mathrm{B}) \text { specimens, } P_{m}=\frac{0.5 B b_{0}^{2} \sigma_{Y}}{S}
$$




$$
\text { For C(T) and } \mathrm{DC}(\mathrm{T}) \text { specimens, } P_{m}=\frac{0.4 B b_{0}^{2} \sigma_{Y}}{2 W+a_{0}}
$$

where:

$\mathrm{b}_{0}$ is the initial uncracked ligament and equals $\mathrm{W}-\mathrm{a}_{0}$ (initial crack size),

$\sigma_{\mathrm{Y}}$ is the effective yield strength and is calculated as the average of the $0.2 \%$ offset yield strength $\sigma_{\mathrm{YS}}$ and

the ultimate tensile strength $\sigma_{\mathrm{TS}}$,

$\mathrm{S}$ is the distance between specimen supports for $\mathrm{SE}(\mathrm{B})$ specimens.

2) The maximum stress intensity during fatigue precracking shall fulfill the requirements in Fig. 6 and Table 1 in the E1921-19. This requirement defines the allowable window for the applied stress intensity during fatigue precracking.

3) The initial crack size after fatigue precracking, $\mathrm{a}_{0}$, shall be $0.5 \mathrm{~W} \pm 0.05 \mathrm{~W}$ for compact, disk-shaped compact, and single-edge notched bend specimens.

4) The crack extension requirements in Fig. 5 and Table 2 in the E1921-19 shall be fulfilled at each of the nine measurement locations defined in section 8.8.1 of the E1921-19.

Side grooves after fatigue precracking are optional however side-grooving will decrease the curvature of the initial crack front. The total side-grooved depth shall not exceed $0.25 \mathrm{~B}$. Side grooves with an included angle of $45^{\circ}$ and a root radius of $0.5 \pm 0.2 \mathrm{~mm}$ are recommended per E1921-19 section 7.7.

\subsection{Fracture toughness testing}

\subsubsection{Apparatus}

Qualified grips and fixtures described in E1921-19 sections 6.2 and 6.3 shall be used in fracture toughness testing. The displacement gauge, load cell, and temperature measurement devices shall be calibrated to related ASTM standards or other recognized national or international standards. One recommended temperature monitoring method is to weld or spot weld each thermocouple wire separately to the specimen.

\subsubsection{Loading rate}

Quasi-static loading rate such that $\mathrm{dK} / \mathrm{dt}$ during the initial elastic portion is between 0.1 and 2 $\mathrm{MPa} \sqrt{\mathrm{m}} / \mathrm{s}$ shall be used. Table 4 in E1921-19 provides a proper load-line loading rate which should be applied in testing as a function of $\mathrm{dK} / \mathrm{dt}$ and a/W. Prior to testing, it is necessary to verify that the specimen is properly seated into the loading device and that the clip gage is properly seated. This can be achieved by estimating the specimen crack size while working-in the test setup at the test temperature. Working-in is accomplished via repeated preloading and unloading in the linear elastic range at least three times. For each unloading/reloading sequence, estimate the precrack size using the compliance equations in the ASTM E1820 standard. The elastic modulus, E, used in the crack size estimation should be the nominal value for the material at the test temperature, which shall come from either handbook values or dedicated modulus testing per ASTM test method E111 or equivalent. Alternatively, the following equation can be used to determine the nominal value of $\mathrm{E}$ at the test temperature:

$$
E=204-T / 16 \mathrm{GPa}
$$

where $\mathrm{T}=$ test temperature in ${ }^{\circ} \mathrm{C}$. The set setup is considered acceptable when the last three consecutive estimated crack sizes are all within $10 \%$ of the final precrack size and no individual estimated crack size 
differs from the mean by more than $\pm 0.002 \mathrm{~W}$. To minimize the difference between the precrack size and the working-in estimated crack size, the nominal E value may be adjusted up to $10 \%$.

\subsubsection{Test temperature selection}

Test temperature $\mathrm{T}$ should be chosen such that the medium stress intensity factor $\mathrm{K}_{\mathrm{JCc}(\mathrm{med})}$ at the test temperature will be about $100 \mathrm{MPa} \sqrt{\mathrm{m}}$ for the specimen size selected. For small size specimens, this may not be achievable due to the maximum $\mathrm{K}_{\mathrm{Ic}}$ capacity limit $\left(\mathrm{K}_{\mathrm{Iclimit}}\right)$ defined in Eq. (4). Hence, lower testing temperatures are necessary. For both cases, Table 5 of the E1921-19 shall be consulted to assist the test temperature selection such that $\sum_{i=1}^{3} r_{i} n_{i} \geq 1$ where $\mathrm{r}_{\mathrm{i}}$ is the number of uncensored data within the $\mathrm{i}$-th temperature range of $\left(T-T_{0}\right)$ and $n_{i}$ is the specimen weighting factor for the same temperature range in Table 5. In the extreme case (e.g. miniature bend bar testing), the test temperature may be more than $50^{\circ} \mathrm{C}$ lower than $\mathrm{T}_{0}$ and the testing temperature is selected by balancing between obtaining as high fracture toughness results as possible and still within $\mathrm{K}_{\mathrm{Jclimit}}$.

$$
K_{J c \lim i t}=\sqrt{\frac{E b_{0} \sigma_{Y S}}{30\left(1-v^{2}\right)}}
$$

where:

$\sigma_{\mathrm{YS}}$ is the $0.2 \%$ offset yield strength at the test temperature and can be determined based on E1921-19 section 7.5 ,

$v$ is the Poisson's ratio.

\subsubsection{Pop-in evaluation}

During testing, if pop-in is experienced, the pop-in evaluation according to section 9.2 in the E1921-19 shall be performed to determine if the pop-in event is considered as significant. If so, the specimen shall be considered at the significant pop-in.

\subsection{Post-test crack length measurements}

Upon completion of fracture toughness testing, measurements on specimen fracture surface shall be performed to obtain the initial crack size, $\mathrm{a}_{0}$, and the ductile crack growth, $\Delta \mathrm{a}$, where applicable. If the specimen failed in cleavage, the two halves of the specimen can be easily separated by the test frame and the crack length measurement follows. If the test finished without cleavage fracture from the specimen, either fatigue loading to create beach marks shall be performed before break the specimen or loading the specimen at liquid nitrogen temperature can be used to separate two halves of the specimen. This will make sure the fracture surface is preserved for the crack size measurement. The crack size should be measured at nine equally spaced points centered about the specimen centerline and extending to 0.01B from the free surfaces of plane sided specimens or near the side groove roots on side grooved specimens. Average the two near-surface measurements and combine the average of these two readings with the remaining seven crack measurements. Determine the average of those eight values.

\subsection{Fracture toughness calculation, validity check, and censoring}

Force-displacement data shall be used to calculate $\mathrm{K}_{\mathrm{Jc}}$ (elastic-plastic equivalent stress intensity factor derived from the J-integral at the point of onset of cleavage fracture) based on procedures outlined in section 9.1 of E1921-19. The $\mathrm{K}_{\mathrm{Jc}}$ datum shall be considered invalid if any of the nine physical measurements of the starting crack size differ by more than $0.1\left(b_{0} B_{N}\right)^{1 / 2}\left(B_{N}\right.$ is the net thickness) from the 
average starting crack size. The datum is also invalid if the calculated crack length for the test determined in E1921-19 section 8.8.2 differs from the optical average value determined in section 8.8.1 by more than $5 \%$. For valid $\mathrm{K}_{\mathrm{Jc}}$ datum, if it exceeds maximum $\mathrm{K}_{\mathrm{Jc}}$ capacity limit $\mathrm{K}_{\mathrm{Jclimit}}$ and/or slow stable crack growth $\mathrm{K}_{\mathrm{Jc}}$ limit $\mathrm{K}_{\mathrm{Jc} \Delta \mathrm{a}}$, the datum will be censored based on procedures in E1921-19 section 8.9.2. If both $\mathrm{K}_{\mathrm{Jclimit}}$ and $\mathrm{K}_{\mathrm{Jc} \triangle \mathrm{a}}$ are violated, the lower value of the two shall be used to replace the $\mathrm{K}_{\mathrm{Jc}}$ datum for data censoring purposes in the analysis. Once the provision reference temperature $\mathrm{T}_{0 \mathrm{Q}}$ is calculated, follow procedures in E1921-19 section 10.5 to check if $\mathrm{T}_{0 \mathrm{Q}}$ can be validated as the Master Curve reference temperature $\mathrm{T}_{0}$.

\section{Recording}

All the testing parameters and results should be input into the excel spreadsheet template entitled "IAEA SSTT Master Curve record sheet."

\section{Acknowledgements}

This study was supported by the U.S. Department of Energy, Office of Fusion Energy Sciences under contract DE-AC05-00OR22725 with ORNL managed by UT Battelle, LLC. The work performed at UKAEA has been partially funded by the RCUK Energy Programme [grant number EP/T012250/1].

\section{References}

[1] ASTM E1921-19b ${ }^{\mathrm{e}}$, Standard Test Method for Determination of Reference Temperature, To, for Ferritic Steels in the Transition Range, ASTM International, West Conshohocken, PA, 2019, www.astm.org 